\title{
"My body pinned down": Gender Construction, Disruptive Form, and the Language of Sexual Violence in Elly Danica's Don't: $A$ Woman's Word and Beckylane's Where the Rivers Join
}

\author{
T. L. Cowan
}

\begin{abstract}
Par une lecture dialectique de la forme et du fond narratifs, cet article examine comment Don't: A Woman's Word d'Elly Danica et Where the Rivers Join de Beckylane - deux récits autobiographiques d'abus sexuels dans l'enfance réconcilient l'impasse fondamentale entre la fragmentation poststructuraliste et l'entité unifiée de la politique identitaire. En avançant comme argument que Danica et Beckylane se placent elles-mêmes au centre de cette tension entre la forme (qui, dans le cas de ces textes, est perturbatrice et expérimentale) et le fond (qui, sur la base des expériences racontées dans ces textes, reproduit nécessairement l'idéologie du genre binaire), cet article insiste en outre sur l'utilité politique et critique de maintenir les élans contradictoires dans un texte.
\end{abstract}

\section{You may not believe in gender but gender believes in you. Teresa Senft (15)}

In the first chapter of her landmark book, Technologies of Gender (1987), Teresa de Lauretis urges political and critical change in how (feminist) scholars approach the problem of gender:

\begin{abstract}
we need a notion of gender that is not so bound up with sexual difference as to be virtually coterminous with it and such that, on the one hand, gender is assumed to derive unproblematically from sexual difference while, on the other, gender can be subsumed in sexual differences as an effect of language, or as pure imaginary-nothing to do with the real. This bind, this mutual containment of gender and sexual difference(s), needs to be unraveled and deconstructed. (2)
\end{abstract}

This critical and political necessity for the separation of (binary) sexual difference and the social category of gender has become self evident perhaps in the 18 or so years since de Lauretis' exhortation. Certainly third wave feminists organize around "the lived messiness" of the experiences of a multitude of gender positions: "girls who want to be boys, boys who want to be girls, boys and girls who insist they are both" (Haywood and Drake 8). However, while queer and academic communities regularly engage in non-binary language practices, outside of these communities binary gender language remains a seemingly 
instinctive organizing principle. Therefore, because mainstream gender remains ideologically encoded by binary sexual difference (what I like to call fundamentalist gender), materialist feminists rightly insist that scholars critically examine the practice of talking about gender in the abstract and account for the lived experiences of women (as socially sexed subjects) in our critical/scholarly/artistic work. ${ }^{i}$ This paper will discuss how two texts which engage with materialist language/content and poststructuralist form can be read as providing a strategy for moving through this ongoing impasse.

By suggesting that the writing/healing process marks an effort to recuperate an ideal whole, true female self, Elly Danica's Don't: A Woman's Word and Beckylane's Where the Rivers Join engage in conservative gender and subject constructions in order to re-present their childhood experiences of abuse; the distuptive narrative and formal strategies of these texts, however, suggest that Danica and Beckylane might be simultaneously engaged in challenging this ideal..$^{\text {ii }}$ By writing in fragments of memory flashbacks and producing a disjointed, interrupted narrative, Don't and Where the Rivers Join enact an important and productive tension between disruptive form/narrative syntax and a rehabilitative subject positioning. By considering the way that Danica and Beckylane position their subjects/selves at the centre of this tension between form and content, it becomes clear how these narratives might function to reconcile the problem between poststructuralist efforts (which run the risk of eschewing the possibility of any stable identity and therefore the likelihood of political action) and emancipatory narrative practices based in identity politics (which, as we have learned through the past two decades of feminist scholarship, tend to elide differences in order to produce and maintain a coherent political agenda). While I am attentive to the risks involved in privileging formally innovative texts as "the most authentically resistive practice" (Felski 28) and at the risk of "legislating a 'correct' approach" (Bordo 135) to theorizing or narrativizing gender violence, I will argue that Don't and Where the Rivers Join engage in disruptive language practices that require serious consideration. Whether or not innovative form offers enough of a challenge to binary gender language codes, or whether we can/should engage critically with texts which do not formally undermine stable subject and gender positioning, is perhaps an argument that scholars will continue for decades to come.

not the body. my body I have no body. I want my body back. Beckylane (142)

In "Writing 'in Sparkler Script': Incest and the Construction of Subjectivity in Contemporary Canadian Women's Autobiographical Texts," Jodi Lundgren argues,

[f]or an incest survivor, the body is the site of oppression, and so the body must be recuperated for healing to occur. To enact-not recount-recovery from incest, a text must deviate from the standard of traditional autobiography: the disembodiment characteristic of the universal self is counterproductive to healing. (237) 
The personal narrative of an incest survivor, then, is necessarily an embodied text, a text informed and produced by the ways in which the survivor/her body has been constructed, damaged, and reclaimed. The ideology of sexual difference (man/woman, male/female) produces sexual violence, (or put another way, sexual violence finds it's raison d'être in the ideology of binary sexual difference), and thus, a writer putting into narrative her experience of sexual violence would be hard pressed to articulate gender as anything other than the real experiences which enact the relations of power between a man and a girl/woman. Deconstructing binary gender requires that one envision possibilities outside of the male/female dyad, an improbable project for an autobiographical subject who has lived through years of misogynist violence. As Shirley Neuman posits,

[a]lthough the biological, material characteristics of sexed bodies exist on a broad continuum, their social coding into the categories of male and female has the effect of polarizing differences at the expense of the many possible positions along the continuum and of constructing gender relations in terms of heterosexual relations" (Neuman 294).

When a woman is repeatedly violated because of her sexual anatomy and the degraded gender position which accompanies her generalized anatomy, the language of sexual difference will inescapably inform her narrative of that violence. However, as I will illustrate in the coming pages, forms which disrupt linear narrative syntax implicitly problematize dichotomous gender positions by refusing the apparati which normally buttress the binaries of humanist western culture and society. ${ }^{\mathrm{iii}}$

My body is my only clue. It's the only thing I couldn't compromise or rationalize. It was there. My mind and feelings could go away but my body was there and had to be there the whole time.

Michelle Smith (qtd. in Beckylane 81)

A female body is centre stage throughout Beckylane's narrative. It is figured as the girl-child's body that was abused by her father (and thus a man's body also plays a prominent role in these sections):

$$
\begin{aligned}
& \text { go away go away daddy } \\
& \text { he masturbated himself with }
\end{aligned}
$$

my arm my hand held there

my body pinned down

my arm wretched wrenched bending back behind

my back him on me heavy penis hot hard on

my bum

my arm forced back (10) 
Along with the anatomized physicality of the sexual violence, Beckylane also articulates a range of gendered endearments which accompany the violence, and which serve to reinforce conventional gender and to produce contradictory violence inherent in the formation of her gender identity:

she'll hug the pig now won't you my little angel

numb I shake my head
yes
$\begin{aligned} & \text { I take off the dress slip and panties white I hug the pig } \\ & \text { red she's scared and blood and warm } \\ & \text { and kind of quiet }\end{aligned}$

be a good little girl now

they watch the show now

no

I won't (17)

The above two passages are emblematic of the flashback snapshots that make up the narrative of abuse in Where the Rivers Join. Beckylane's "no/I won't" at the bottom of the second passage reveals a split between the young girl and the woman who is writing the text: the woman/writer has decided not to "be a good little girl now". However, while she is writing in defiance of the father who called her a "little angel" as he raped her during most of her childhood and adolescence, Beckylane cannot write outside of the gender codes which inform the violence: "I am my body. my body is me. [. . .] I am a woman" (32). Her body is her knowledge, and thus she must reclaim her female sex in order to heal from the violence.

Much has been written about the body/bodies in women's autobiographical writing. Smith writes, "some kind of history of the body is always inscribed in women's autobiographical texts" (Smith 1994, 271). The particular history of the body in Where the Rivers Join and Don't is a history marked not only by physical sexual violence, but also by the framing of their bodies in the language of sexual denigration:

blood and blood gushes down my legs

you are a dirty evil child this is your dirty evil place

the cunt your cunt is filthy your cunt is filthy stop your bitching or I'll never stop stop your crying shut your mouth 
This is because you're ugly. This is so you'll learn you are a woman. I know how to hurt you so there are no bruises. I'm not stupid. Stupid is female. Stupid cow. Stupid slut. Do what I tell you. Open your mouth. Put it in. If you bite again I'll kill you. Simple. (Danica 8-9)

By using the language with which their bodies have been inscribed- "you're the devil's cunt" (Beckylane 90); "Kid's got no brains. Just a stupid cunt." (Danica 11)-Beckylane and Danica write the history of sexual violence, and a history of being their sexual anatomy, which becomes the histories of their bodies. Rather than articulate a subject position which is "multivalent" or their bodies as "the site of heterogenous axes of signification" (Smith 1994, 270-1), these writers position themselves as victimized female bodies in relation to powerful and dangerous male bodies. iv

As their bodies are textualized in the process of writing out their experiential physical histories, both Danica and Beckylane complicate the issue of healing, wholeness, and the representative im/possibilities of language. While Beckylane is working towards healing "the gap" (226) of/in her life, the gap between her adult self and her child self-"I'm big and you are small. you're a precious little girl and no one should hurt you" (225) - the final lines of Where the Rivers Join retain a sense of an unstable, historically situated subject: "me a messenger gaping holes wind blows through/from the past" (227). Danica, on the other hand, closes her narrative with a picture. As Janice Williamson observes, "[t]he utopian body of Danica's 'Ikon' provides a visual correlative to Danica's recuperation in language of a body capable of subjective pleasure" (231). The "vaginal imagery" (Williamson 232) of Danica's "Ikon" is a reclamation of female anatomy, which is problematic in that it constitutes her subject in the image of a vagina, thereby remaining in, and reinforcing, the discourse of sexual difference and anatomical determinism. The final line of Danica's linguistic narrative, "I am" (94), faces "Ikon" on the adjacent page, and thus the two statements (linguistic and non-linguist) work together, the drawing standing in for a sense of self that words alone cannot achieve. This ultimate, if subtle, "correlative" or corrective to the text works to supplement the representative function of language, thereby exposing the limitations of language to represent experience.

The over-determined, anatomized female body is textualized and constructed by Danica and Beckylane, using what Rosemary Hennessy calls the "available knowledge in a culture as they circulate in discourses and institutional practices" (37). I have illustrated how the "available knowledge" of radical and incommensurable sexual difference have informed and produced these female bodies, rendering them essentially static: Danica and Beckylane know and represent their bodies in the language/discourse of sexual violence. The experiences of their bodies are written through and by the practice of rape and other forms of sexual abuse. However, as Smith writes in Subjectivity, identity, and the body: women's autobiographical practices in the twentieth century, women writing autobiography often do so as a means of "talking back" against the "historically imposed" images of women, and of the female body, which are "culturally 
assigned them" (20). Smith continues, noting that when these women "enter the scene of autobiographical writing, they engage dialogically with the cacophonous voices of cultural discourses" (21). In the following section of my paper, I will discuss how cultural discourses dialogically and/or intertextually enter Don't and Where the Rivers Join, and how, by engaging with these discourses, each writer exposes the ways in which, to use de Lauretis' term, the "technologies of gender" operate to produce and maintain gender ideologies, which "rigidly script identities and differences according to apparently 'natural' or 'God-given' distinctions" (Smith 1993, 21). Furthermore, as Smith reminds us, "these cultural scripts of difference remain vulnerable to contradictions from within and contesting social dialects from without that fracture their coherence and dispute their privileges" (21). Therefore, in the process of exposing these "technologies of gender" Danica and Beckylane undermine their cultural power and reveal how the language of sexual difference is used as violence.

Danica engages with the institutionalization of sexual difference/violence by relaying a conversation with her school teacher:

I try to tell my teacher at school. She says: You are subject to your father in all things. He is your lord as jesus is your lord. He would do no harm or no wrong. He is right in all things. If you are punished or hurt it is for your own good. If he is too rough it is because he loves you. Pray to jesus for comfort. (15).

The teacher, a representative of two public institutions, the school and the Church, refuses to acknowledge the child's experience and instead reinforces the father's absolute power by investing him with sacred authority. In the process of making her own text, however, Danica re-scripts this narrative and divests the teacher of authority by refusing to capitalize "jesus" and "lord". The small-case letters can be read as an act of rebellion, defiance against the public institution, a makingridiculous of the teacher's response, yet not stripping that response of its inherent cruelty. Danica thus engages dialogically with the power of the Church by manipulating language and textual representation - the reproduction of the teacher's words becomes polyphonic for it incorporates both the teacher's words (as Danica presents them) and Danica's irreverent response. ${ }^{v}$

Beckylane engages public discourse on a different level. She begins Where the Rivers Join with "Letter to Beckylane: RE: DEFAMATION AGAINST OUR CLIENT" wherein she is threatened with a lawsuit for making "serious allegations against" her father. Public discourse and power, then, serve to repress and/or stifle her narrative and Where the Rivers Join is engaged, from its beginning pages, with the legal system. Beckylane also situates her personal account of incest and ritual abuse within the context of literature, policy, and other testimonies about/of ritual abuse, incest, and trauma and includes fragments of a checklist from a "Ritual Abuse Taskforce":

Does the child report being defecated and urinated upon; report having to ingest both? Does the child describe the torture and killing of animals (may include drinking their blood)? (5-6) 
Where the Rivers Join differs from Don't in that it is very conspicuously intertextual. White space, idiosyncratic line breaks, jarring juxtapositions, montage, sentence fragments, are all textual strategies which draw attention to the experiment of Beckylane's narrative. By including the testament of other survivors Beckylane writes herself into a community, creates at least the perception of a collective subjectivity, and implies a collective voice shared by this community of survivors. This voice is simultaneously one and many, as Beckylane does not integrate other voices into her own narrative, but rather places them side by side, makes a montage of them, binds them together between book covers, and allows them to reside as multiple voices/narrators of one story/many stories.

The disruptive textual and narrative forms used by both Danica and Beckylane create at least two very specific effects. First, by refusing a conventional narrative approach, by using snapshot-esque diary entries, flashback sequences, non-linear storytelling techniques, sentence fragments, and numbered (in the case of Don't) or dated (Where the Rivers Join) blocks of text, they trouble readers by making them "work hard" (Beckylane 9). These texts are written against the grain, and the reader has to piece together a story from the fragments provided by the writer; the reading is interrupted, jarring, never smooth or cohesive. The reader must not only grapple with the content of these texts, which is disturbing and difficult, but must also wrestle with the style, must try to figure out why the book is written this way. Second, by writing autobiographically in a nonconventional way, by making the textuality of the book conspicuous, Don't and Where the Rivers Join draw attention to the materiality of the books themselves: they make obvious the body of the text, the editing, the physical realities of the text. The materiality of the books then, works in conjunction with the narrative content, which is occupied with the physical conditions of the writers' lives, and the material experiences and ideological production of their bodies. By disrupting the grammar of narrative, however, by drawing attention to language as language and to form as form, these texts destabilize the structural and regulatory presuppositions of the humanist subject.

subjectivity is not to be found in processes, only in content and strategies, that is, in the stylistic devices we use to accommodate our subjectivity.

Nicole Brossard (150)

The textual strategies mobilized by Danica and Beckylane force an awareness of the corporeal elements of the texts/bodies, yet the narrative reliance on fragmentation, dialogic writing, and intertextuality creates a reading environment that is not entirely conducive to corporeal essentialism. The contradictions between form and content create a productive tension and convergence wherein stories of the body can be experienced through a text that simultaneously accepts and problematizes sexual difference. My argument here is that the disruptive form of the texts gestures towards a politics of fragmentation wherein the binaries of liberal humanism and its accompanying binaries are troubled. However, the writing of the body simultaneously undermines a complete disavowal of the "truth" or "realness" of gender, thereby throwing the text into a constant and productive 
state of flux between the experiences of the socially sexed body and the ideological production of binary gender.

At the beginning of this paper I indicated my reluctance to read these texts as "correct" or "authentically resistive" because their disruptive formal practices somehow redeems their problematic (binaried) approach to gendered experience. In my mind I refer to this as the "yes, but" approach to literary scholarship. (Question: This text relies on biological essentialism in its representation of gender. Answer: Yes, but it uses idiosyncratic style and challenges language structures, which necessarily call into question those categories. And vice versa.) Others who have commented on Danica (in particular) have utilized similar "yes, but" strategies in their readings. Linda Warley argues that Danica writes out of "a third position. She lives in the contradictory position in between" (79). Warley suggests that, while Don't may "not have totally freed itself from the repressive structures of patriarchy, Danica succeeds in "finding, exposing, and exploring the cracks in the logic of patriarchy" (79). Janice Williamson claims that Danica's final claim to have found her body is not the result of a Cartesian mind/body split, but of an embodied politic and artistic practice:

\begin{abstract}
Writing reconstitutes the writer's body and world making survival possible in a sensorium of particulars: 'Fingernails. Teeth. Determination' (93). These particulars are not simply body parts organized by a consciousness informed by the body/mind inner/outer split and hierarchy of Cartesian dualism. The physical body is inhabited by 'determination' and will. (231)
\end{abstract}

Jodi Lundgren performs a similar critical maneuver. She notes that "whether or not her notion of self is essentialist, the metaphor of reintegration clearly functions as an enabling fiction for Danica" (241), and yet cautions that this "enabling fiction" of a coherent self "denies the impact of social positioning" and "can thus function to maintain oppressive hierarchies of difference" (241). Lundgren thus problematizes the essentialism of Don't and then performs her final critical porté, suggesting that Don't "emphasize[s] the discursive construction of subjectivity, which enables the resignification and subversion of the deformed identities interpellated by the abusers" (245).

While few critics have approached Where the Rivers Join, one reviewer notes,

[t] he author is so obsessed with the accusation of False Memory Syndrome that she constantly foregrounds a critique of her own material that compels the sympathetic reader to become a skeptical judge. Ultimately, as she insists, this brave book is primarily a therapy for herself and other abuse survivors (Pell 113). 
By forcing the reader to "become skeptical judge," Beckylane might be understood to have scored a poststructuralist 3-pointer while concurrently being read as "brave" for telling this story of sexual violence.

I have provided this brief summary of the critical work surrounding Don't and Where the Rivers Join in order to make the case that these are problematic texts because, while they seem to demand that feminist scholars embrace them, they also produce a critical discomfort that makes scholars like myself (and arguably those mentioned above), feel compelled to distance themselves from the constructions of gender they reproduce. I suggest that it is the very things that make us uncomfortable about these texts that make them valuable to us. Not only do they, as Lundgren writes, "stage struggle and resistance" (245), they also exemplify the very contradictions in our critical objectives: we want to embrace free play and challenge the meaning of narrative, while at the same time we need to account for the physical and social realities of an oppressive world. It is, thus, somewhere in the middle of these mixed messages that we can understand the confusing im/possibilities and im/practicalities of bodies and the language forms through which we know them.

\section{Notes}

i I borrow and amend the phrase "socially sexed" from de Lauretis' usage of Monique Plaza's term (37).

ii Beckylane is a pseudonym for Sharron Proulx-Turner, who has, since the publication of Where the Rivers Join, identified herself as the author of the text. See Sharron Proulx-Turner "healing and dis-ease: a return to mother to creation to movement," Crisp Blue Edges: Indigenous Creative Non-Fiction, Ed. Rasunah Marsden- (Penticton: Theytus Books, 2000, 171-179).

iii While many critics have remarked on this tendency, an excellent discussion can be found in Erin Mouré and Bronwen Wallace's Two Women Talking: Correspondence 1985-1987, Ed. Susan McMaster (Ottawa: Feminist Caucus League of Canadian Poets, 1993).

iv Gender remains the primary way in which each writer establishes the "relationship of her specific body to the cultural 'body' and to the body politic" (Smith 1993, 131). Danica also identifies as an immigrant to Canada and Beckylane positions herself as "lower working class" (132) and provides a couple of clues to her Métis identity.

$v$ Both Lundgren and Warley have made similar arguments about the ways in which Danica exposes the lies of patriarchal discourse. 


\section{Works Cited}

Beckylane. Where the Rivers Join: A Personal Account of Healing From Ritual Abuse. Vancouver: Press Gang, 1995.

Butler, Judith. Bodies that Matter: On the Discursive Limits of Sex. New York \& London: Routledge, 1993.

Bordo, Susan. "Feminism, Postmodernism, and Gender-Scepticism [sic]." Feminism/Postmodernism. Ed. Linda J. Nicholson. NY: Routledge, 1990. 133-156. Brossard, Nicole. The Ariel Letter. Trans. Marlene Wildeman. Toronto: The Women's Press, 1988.

Danica, Elly. Don t: A Woman's Word. Charlottetown, P.E.I.: Gynergy Books, 1988. de Lauretis, Teresa. Technologies of Gender: Essays on Theory, Film, and Fiction. Bloomington and Indianapolis: Indiana UP, 1987.

Felski, Rita. The Gender of Modernity. Cambridge MA: Harvard UP, 1995.

Haywood, Leslie and Drake, Jennifer. Introduction. Third Wave Agenda: Being Feminist, Doing Feminism. Eds. Leslie Haywood and Jennifer Drake. Minneapolis: U of Minnesota P, 1997. 1-20.

Hennessy, Rosemary. Materialist Feminism and the Politics of Discourse. New York: Routledge, 1993.

Lungren, Jodi. "Writing 'in Sparkler Script': Incest and the Construction of Subjectivity in Contemporary Canadian Women's Autobiographical Texts." Essays on Canadian Writing. 65 (Fall 1998): 233-47.

Neuman, Shirley. "'An appearance walking in a forest the sexes burn': Autobiography and the Construction of the Feminine Body." Autobiography and Postmodernism. Eds. Kathleen Ashley, Leigh Gilmore, Gerald Peters. Boston: U of Massachusetts P, 1994. 293-315.

Pell, Barbara. Review. Where the Rivers Join: A Personal Account of Healing form Ritual Abuse. Canadian Literature. 154 (Fall 1997): 113.

Senft,Theresa M. "Introduction: Performing the Digital Body-A Ghost Story." Women \& Performance: A Journal of Feminist Theory. 17. 9-1 (1996): 9-33.

Smith, Sidonie. "Identity's Body." Autobiography and Postmodernism. Eds. Kathleen Ashley, Leigh Gilmore, Gerald Peters. Boston: U of Massachusetts P, 1994. 266-291.

- Subjectivity, identity, and the body: women's autobiographical practices in the Twentieth Century. Bloomington: Indiana UP, 1993.

Warley, Linda. "Inhabiting Contradiction: The Female Subject in Don't: $A$ Woman's Word." Open Letter. 8.2 (Winter 1992): 70-80.

Williamson, Janice. "II Peel Myself Out of My Own Skin': Reading Don't: A Woman's Word." Women's Writing and the Literary Institution / L'écriture au féminin et l'institution littéraire: Towards a History of the Literary Institution in Canada: $6^{\text {th }}$ Conference. November 1989. Eds. Claudine Potvin and Janice Williamson. Edmonton: Research Institute for Comparative Literature, University of Alberta, 1992. 219-235. 